\title{
Pokdarwis: Agen Pengembangan Wisata Geopark Ranah Minang Silokek
}

\author{
Gusrinda Gusrinda ${ }^{1}$, Erda Fitriani ${ }^{2}$ \\ ${ }^{1}$ SMP IT Kautsar Ilmi Sijunjung, ${ }^{2}$ Universitas Negeri Padang \\ Email: gusrinda6@gmail.com, fitriani_cim@fis.unp.ac.id.
}

\begin{abstract}
Abstrak
Penelitian ini bertujuan untuk mendeskripsikan Pokdarwis sebagai agen pengembangan wisata Geopark Ranah Minang Silokek khususnya di Nagari Silokek Kabupaten Sijunjung. Penelitian ini dianalisis dengan menggunakan teori agen dan struktur dari Pierre Bourdieu. Penelitian dilakukan dengan pendekatan kualitatif dengan tipe penelitian studi kasus. Pemilihan informan dilakukan dengan teknik purposive sampling dengan jumlah informan sebanyak 23 orang. Pada penelitian ini peneliti melakukan pengumpulan data dengan cara observasi, wawancara mendalam dan studi dokumentasi, untuk mendapatkan data yang valid dilakukan trianggulasi data. Analisis data yang digunakan adalah model analisis interaktif dari Mills dan Huberman yaitu reduksi data, sajian data dan penarikan kesimpulan. Hasil penelitian ini mengungkapkan bahwa Pokdarwis melakukan berbagai tindakan sebagai agen dalam rangka mengembangkan wisata Geopark Ranah Minang Silokek. Tindakan yang dilakukan Pokdarwis tetap berdasarkan pada tugas pokok sebagai Pokdarwis. Tindakan ini berupa kerjasama, promosi, dan pelatihan, pemberdayaan masyarakat dan eksplorasi wisata baru. Sebagai kelompok penggerak, Pokdarwis menjadi tolak ukur bagi masyarakat dalam berinteraksi dengan wisatawan. Masyarakat secara tidak langsung dipengaruhi dengan adanya berbagai kegiatan yang dilakukan Pokdarwis. Pengaruh Pokdarwis terhadap masyarakat berdampak pada struktur masyarakat.
\end{abstract}

Kata kunci: Agen, Ekowisata, Pokdarwis, Tindakan, Pembangunan berkelanjutan, Wisata Geopark

\section{Abstract}

This study aims to describe how Pokdarwis as a tourism development agent for the Ranah Minang Silokek Geopark, especially in Nagari Silokek Kabupaten Sijunjung. This research was analyzed by using agent and structure theory from Pierre Bourdieu. The research was conducted with a qualitative approach to the type of case study research. The selection of informants was carried out by purposive sampling technique with a total of 23 informants. In this study, researchers collected data by means of observation. in-depth interviews and documentation studies to obtain valid data, triangulated the data. The data analysis used is an interactive analysis model from Mills and Huberman, namely data reduction, data presentation and conclusion drawing. The results of this study revealed that Pokdarwis took various actions as agents in order to increase the number of tourists in the Minang Silokek Geopark tourism. The actions taken by Pokdarwis are still based on their main duties as Pokdarwis. These actions take the form of cooperation, promotion, and training, community empowerment and the new toursm exploration. As a driving group, Pokdarwis is a benchmark for the community in interacting with tourists. The community is indirectly affected by the various activities carried out by Pokdarwis. The influence of Pokdarwis on society has an impact on the structure of society.

Keywords: Agent, Ecotourism, Pokdarwis, Action, Sustainable Development, Geopark Tourism. 


\section{Pendahuluan}

Pengembangan destinasi wisata dengan konsep ekowisata menjadi alternatif pilihan pengembangan wisata berkelanjutan. Pengembangan destinasi wisata dengan konsep ini menjadi salah satu kunci menjaga eksistensi objek wisata dengan mempertimbangkan aspek lingkungannya. Proses pengembangan wisata yang tidak terencana dengan baik akan menyebabkan daerah wisata mencapai fase stagnasi atau tidak adanya kemajuan dalam jangka waktu yang pendek (Hidayat, 2011). Penetapan konsep ekowisata ini sangat cocok untuk destinasi wisata yang berbasis Geopark salah satunya di Geopark Ranah Minang Silokek yang ada di Kabupaten Sijunjung. Geopark ini sudah ditetapkan sebagai Geopark Nasional ditandai dengan penyerahan sertifikat geopark nasional oleh Menteri Pariwisata, Arif Yahya kepada Bupati Kabupaten Sijunjung, Yuswir Arifin di Museum Tambang Antam Kecamatan Nanggung Kabupaten Bogor, Jawa Barat pada tanggal 30 November 2018 (Kusuma, 2019). Lokasi Geopark Ranah Minang Silokek ini yang berada di dua Kecamatan yakni Kecamatan Sijunjung dan Kecamatan Sumpur Kudus, menetapkan Nagari Silokek yang Berada di Kabupaten Sijunjung sebagai Icon (sentral) dari Geopark Ranah Minang Silokek.

Sebelum menjadi Geopark Nasional, wisata di Nagari Silokek ini tergabung dalam wisata Musiduga (Muaro Silokek Durian Gadang) pada tahun 2016. Kawasan Musiduga yang saat ini lebih dikenal dengan nama Geopark Ranah Minang Silokek memiliki potensi ekowisata seperti penelitian yang pernah dilakukan dengan judul strategi pengembangan kawasan ekowisata Musiduga melalui pendekatan arsitektur (Amelia, 2016). Berdasarkan keputusan Bupati Sijunjung Nomor: 188.45/338/KPTS-BPT-2016 tentang penetapan kawasan wisata strategis dan destinasi pariwisata di Kabupaten Sijunjung telah ditetapkan 66 objek wisata yang terdiri dari 46 objek wisata alam, 12 objek wisata budaya, dan 8 objek wisata minat khusus (KIKIP Disparpora Kab. Sijunjung, 2017). Potensi yang ada perlu dikembangkan dengan tetap memberdayakan masyarakat di sekitar kawasan wisata.

Keberadaan wisata Geopark ini juga memberikan peluang kepada masyarakat untuk meningkatkan pendapatan yang berdampak pada kesejahteraannya (Nurwafi, 2015). Dengan dikembangkannya wisata Geopark yang melibatkan masyarakat diharapkan masyarakat berpartisipasi aktif mengelola destinasi yang ada di wisata Geopark Ranah Minang Silokek khususnya di Nagari Silokek. Masyarakat sebagai penerima dampak dari adanya penetapan Geopark Nasional ini dapat berkontribusi melalui Kelompok Sadar Wisata (Pokdarwis) yang ada di Nagari Silokek. Sesuai dengan konsep ekowisata yakni pentingnya pemberdayaan masyarakat lokal dalam pengembangan wisata.

Pokdarwis memiliki peranan yang krusial dalam penggerak masyarakat untuk meningkatkan partisipasi masyarakat yang berada di lokasi wisata untuk turut serta mengembangkan potensi wisata (Putrawan, 2019). Sebagai kelompok yang memiliki simbol sebagai individu yang sadar akan wisata pokdarwis menjadi agen yang memotivasi tindakan masyarakat. Tindakan sosial menurut Max Weber adalah perbuatan penuh arti dari individu yang melakukan tindakan berdasarkan atas pengalaman, persepsi, pemahaman dan atas suatu objek stimulus maupun situasi tertentu (Schott, 2012). Dengan hal ini anggota pokdarwis akan bertindak berdasarkan atas pengalaman yang dimilikinya dari adanya dorongan sebagai seorang agen yang berstatus Pokdarwis.

Dalam mencapai tujuan untuk meningkatkan jumlah kunjungan wisatawan di Nagari Silokek tindakan yang dilakukan Pokdarwis sangat menentukan terwujudnya tujuan tersebut. Berdasarkan data dari Dinas Pariwisata Pemuda dan Olahraga tahun 2019 menunjukkan bahwa wisata Geopark Ranah Minang Silokek merupakan wisata dengan jumlah kunjungan terbanyak di Kabupaten Sijunjung dalam 5 tahun terakhir. Akan tetapi kepopuleran suatu destinasi wisata tidak menentukan tingkat kepuasan wisatawan, niat kunjungan ulang dan rekomendasi wisata (Nurlestari, 2016). Daya tarik wisata tidak hanya keindahan alam namun juga berbagai pengalaman jelajah dan olahraga ekstream yang ditawarkan di wisata Geopark Ranah Minang

Culture \& Society: Journal of Anthropological Research Vol. 3, No. 1, Th. 2021 
Silokek ini. Kepuasan wisatawan akan sangat dipengaruhi oleh kinerja layanan pengelola dan destinasi yang ditawarkan, apabila tidak sesuai dengan ekspektasi maka akan muncul kekecewaan dan ketidak puasan wisatawan (Coban, 2012). Dalam situasi seperti ini agen pengembangan wisata Geopark Ranah Minang Silokek menjadi tanggungjawab Pokdarwis. Tindakan Pokdarwis yang berada di lokasi wisata dan berinteraksi langsung dengan wisatawan sangat menentukan tingkat daya tarik wisata dari berbagai bentuk pelayanan yang ada.

Penelitian mengenai wisata Geopark sudah dilakukan oleh Abdul Rauf dan Fitri Eriyanti (Rauf, 2019) membahas tentang pemanfaatan rumah gadang yang berada di kawasan perkampungan adat nagari Sijunjung sebagai tempat penginapan bagi wisatawan yang akan berwisata ke kawasan Geopark Ranah Minang Silokek. Berbeda dengan penelitian yang akan peneliti lakukan mengenai kerja sama dari kelompok sadar wisata yang ada dalam mengembangkan destinasi wisata di kawasan Geopark Ranah Minang Silokek.

Selain itu penelitian mengenai pariwisata, sudah dilakukan oleh banyak peneliti (Umam, 2019) menunjukkan bahwa pelatihan terhadap Pokdarwis memberikan dampak positif meningkatkan kompetensi Pokdarwis dalam memandu wisata. Penelitian sebelumnya yang sudah pernah mengkaji tentang Pokdarwis ini juga dilakukan oleh Reza Agus Fanzuri, 2020; Agung Suryawan, 2016; MA Afrianto, 2016; Khairul Amri Assidiq, 2021. Perbedaan penelitian yang dilakukan dengan penelitian yang sudah ada yaitu penelitian ini difokuskan pada mengkaji pokdarwis sebagai agen pengembangan wisata Geopark Ranah Minang Silokek, dan hal ini menjadi kebaruan dari penelitian ini.

Berdasarkan pada observasi yang peneliti lakukan pada bulan April 2021, bahwa Pokdarwis di kawasan wisata Geopark Ranah Minang Silokek memiliki banyak kegiatan, terlihat adanya kunjungan ke sekolah-sekolah dari tingkat Taman Kanak-kanak hingga SLTA, dan melakukan kunjungan di wisata Geopark Nagari Silokek. Pesatnya perkembangan wisata Geopark Ranah Minang Silokek terutama di Nagari Silokek dan keaktifan Pokdarwis menjadi salah satu ketertarikan peneliti. Penelitian ini dapat membantu Pokdarwis Geopark Ranah Minang Silokek khususnya yang berada di Nagari Silokek dalam mengembangkan potensi wisata yang ada dan kemajuan wisata untuk kedepannya. Bagi Pemerintahan Nagari Silokek Agar dapat mengambil tindakan yang tepat dalam meningkatkan kesejahteraan masyarakat melalui pariwisata yang ada di Nagari Silokek. Pariwisata juga bermanfaat untuk memajukan perekonomian masyarakat sekitar kawasan wisata. Pokdarwis sebagai agen yang memberikan pengaruh terhadap pengembangan destinasi wisata dan mewujudkan tujuan pengembangan Geopark Ranah Minang Silokek.

Penelitian ini dianalisis dengan teori agen dan sruktur dari Pierre Felix Boudieu atau yang lebih akrab di panggil Pierre Bourdieu. Bourdieu lahir 1 Agustus 1930, meninggal 23 Januari 2002 seorang tokoh pemikir sosiologi dari Prancis. Teori agen dan struktur ini diungkapkan Bourdieu dengan konsep habitus, ranah/field, dan modal yang menjadi praktik sosial (Harker, 2009). Habitus dinyatakan sebagai kebiasan yang terus berulang dibentuk oleh lingkungan dan dilakukan berdasarkan kebutuhan agen. Kebiasaan ini akan dibawa ke suatu arena/field yang dapat mempengaruhi dan menguasai arena tersebut dengan modal yang dimiliki. Modal menurut Bourdieu terbagi atas ekonomi, kultural, relasi sosial dan modal simbolik. Sehingga Bourdieu merumuskan habitus $\mathrm{x}$ modal + ranah $=$ praktik. Agen dapat berupa individu atau kelompok yang dapat mempengaruhi struktur sehingga agen dan struktur membentuk dualitas yang saling memiliki pengaruh terhadap satu sama lain.

\section{Metode Penelitian}

Penelitian ini dilakukan di kawasan wisata Geopark Silokek yang berada di Kabupaten Sijunjung tepatnya di Nagari Silokek. Alasan pemilihan lokasi ini karena Nagari Silokek dijadikan sebagai sentral dari destinasi wisata Geopark Ranah Minang Silokek. Nagari Silokek ini terdiri dari 2 Jorong yakni Jorong Sangkiamo dan Jorong Tanjung Medan. Nagari Silokek dipilih sebagai

Culture \& Society: Journal of Anthropological Research Vol. 3, No. 1, Th. 2021 
lokasi penelitian karena di nagari ini lah Iconik Geopark Ranah Minang Silokek yang dijadikan sentral berbagai agenda kegiatan wisata yang berbasis Geopark.

Penelitian ini dilakukan dengan pendekatan kualitatif. Pendekatan penelitian kualitatif ini berusaha membangun makna tentang suatu fenomena berdasarkan pandangan-pandangan dari para partisipan (Creswell, 2016). Metode ini dipilih dengan mempertimbangkan bahwa metode ini dapat mengungkapkan peristiwa yang terjadi secara detail, dengan tipe penelitian studi kasus yang membahas secara lebih khusus unit sosial masyarakat yang meliputi individu, kelompok, lembaga dan masyarakat itu sendiri. Pemilihan informan dilakukan dengan teknik purposive sampling yakni informan yang memenuhi syarat dalam mendapatkan data yang dibutuhkan dengan jumlah informan sebanyak 23 orang. Informan penelitian yang terdiri dari: 1 orang pedagang di kawasan wisata ini, 2 orang niniak mamak Nagari Silokek, 3 orang staf Dinas Pariwisata, 3 orang Pemerintah Nagari Silokek dan 14 orang pengurus Pokdarwis Nagari Silokek.

Pada penelitian ini peneliti juga melakukan observasi partisipan dengan terjun ke lapangan langsung bergaul dengan pengurus Pokdawis dan terlibat dalam kegiatannya. Wawancara mendalam dilakukan untuk mendapatkan informasi yang lebih terperinci tentang tindakan yang dilakukan Pokdarwis dalam mengembangkan wisata Geopark Ranah Minang Silokek di Nagari Silokek. Pengumpulan data penelitian ini juga menggunakan dokumentasi dari Nagari Silokek dan data dari Dinas Pariwisata Kabupaten Sijunjung. Untuk mendapatkan data yang valid dilakukan trianggulasi data. Analisis data yang digunakan adalah model analisis interaktif dari Mills dan Huberman yaitu reduksi data, sajian data dan penarikan kesimpulan (Hardani, 2020). Metode ini relevan menurut peneliti untuk topik penelitian yang peneliti bahas.

\section{Hasil dan Pembahasan}

\section{Nagari Silokek}

Nagari Silokek adalah salah satu nagari yang berada di Kecamatan Sijunjung Kabupaten Sijunjung yang terdiri dari 2 (dua) jorong yakni Jorong Sangkiamo dan Tanjuang Medan. Berdasarkan data profil Nagari Silokek tahun 2019, batas nagari yaitu: sebelah Utara berbatasan dengan Nagari Durian Gadang, sebelah Timur berbatasan dengan Nagari Aie Angek, sebelah Selatan berbatasan dengan Nagari Muaro sedangkan sebelah Barat berbatasan dengan Kecamatan Sumpur Kudus. Luas wilayah Nagari Silokek adalah 1.918 Ha dengan bentuk permukaan tanah perbukitan yang memiliki ketinggian 150-200 meter dari permukaan laut, suhu rata - rata harian 23-24 derajat celcius pertahun. Hidrologi keadaan sumber air yang masuk ke dalam Nagari Silokek bersumber dari mata air perbukitan.

Sumber Daya Manusia menjadi kunci utama dalam pengembangan suatu daerah. Jumlah penduduk dan tingkat pendidikan menjadi tolak ukur dari kemajuan dan perkembangan suatu daerah. semakin tinggi tingkat pendidikan suatu daerah maka semakin baik sumber daya manusianya. Jumlah dan tingkat pendidikan penduduk di Nagari Silokek dapat dilihat dari tabel di bawah ini:

Tabel 1. Jumlah penduduk Nagari Silokek

\begin{tabular}{ll}
\hline \multicolumn{2}{c}{ Jumlah Penduduk } \\
\hline Jumlah laki-laki & 713 orang \\
\hline Jumlah perempuan & 729 orang \\
\hline Jumlah total & 1442 orang \\
\hline Jumlah kepala keluarga & $410 \mathrm{KK}$ \\
\hline Kepadatan Penduduk & 75,18 per KM \\
\hline
\end{tabular}

Sumber: Data Kependudukan Kantor Wali Nagari Silokek 2019

Berdasarkan pada potensi jumlah penduduk yang berdomisili di Nagari Silokek untuk luas wilayah $1.918 \mathrm{Ha}$ tingkat kepadatan penduduk cukup rendah untuk pemukiman yakni 75,18 per KM. Daerah yang didominasi perbukitan ini menjadikan masyarakat berprofesi di bidang agraria 
atau pertanian dan perkebunan. Sebagai sebuah nagari yang berusia cukup muda masih memerlukan beberapa perbaikan dari berbagai sektor terutama pada sumber daya manusia atau masyarakat sendiri. Nagari yang memiliki potensi alam terutama untuk sektor pariwisata sumber daya manusia sebagai pendukung dalam pengembangan sektor wisata. Sumber daya manusia yang baik akan menghasilkan pengelolaan sumber daya alam yang baik pula dengan tetap menjaga lingkungan sekitarnya.

Dalam meningkatkan Sumber daya manusia yang ada di Nagari Silokek dapat diwujudkan melalui jalan pendidikan. Tingkat pendidikan masyarakat akan mempengaruhi tingkat kemampuan sumber daya manusia nya. Adapun tingkat pendidikan masyarakat ang ada di Nagari Silokek dapat terlihat pada tabel di bawah ini:

Tabel. 2 Tingkat pendidikan masyarakat Nagari Silokek

\begin{tabular}{lll}
\hline \multicolumn{3}{c}{ Tingkat Pendidikan } \\
\hline Tingkatan Pendidikan & Laki-laki & Perempuan \\
\hline Tamat SD/sederajat & 3 orang & 5 orang \\
\hline Tamat SMP/sederajat & 42 orang & 74 orang \\
\hline Tamat SMA /sederajat & 13 orang & 21 orang \\
\hline Tamat D-2/sederajat & 0 orang & 1 orang \\
\hline Tamat S1/ Sederajat & 3 orang & 5 orang \\
\hline Jumlah Total & 167 orang & \\
\hline
\end{tabular}

Sumber: Data Kependudukan Kantor Wali Nagari Silokek 2019

Berdasarkan pada tabel 2 tingkat pendidikan masyarakat Nagari Silokek ini terlihat bahwa tingkat pendidikan masyarakatnya tergolong cukup tinggi. Tingkat pendidikan masyarakat juga berpengaruh terhadap kualitas SDM yang dimiliki. Pendidikan masyarakat juga akan terlihat dari mata pencarian masyarakat itu sendiri. SDM dan mata pencaharian ini beriringan dengan tingkat ekonomi masyarakat di Nagari Silokek. Berikut dapat kita lihat tabel mata pencaharian penduduk di Nagari Silokek:

Tabel 3. Mata pencaharian pokok masyarakat Nagari Silokek

\begin{tabular}{lll}
\hline \multicolumn{3}{c}{ Mata Pencaharian Pokok } \\
\hline Jenis Pekerjaan & Laki-laki & Perempuan \\
\hline Pegawai Negeri Sipil & 3 orang & 5 orang \\
\hline Peternak & 4 orang & 2 orang \\
\hline Belum Bekerja & 120 orang & 103 orang \\
\hline Pelajar & 163 orang & 195 orang \\
\hline Buruh Harian Lepas & 92 orang & 98 orang \\
\hline Petani & 106 orang & 91 orang \\
\hline Jumlah Total Penduduk & \multicolumn{1}{c}{982 orang } \\
\hline
\end{tabular}

Sumber: Data Kependudukan Kantor Wali Nagari Silokek 2019

Berdasarkan pada tabel di atas terlihat pengaruh dari tingkat pendidikan terhadap mata pencaharian masyarakat di Nagari Silokek. Jumlah terbesar berada pada golongan terpelajar yang mengartikan Nagari Silokek terus meningkatkan SDM melalui pendidikan dan mata pencaharian masyarakatnya. Pemerintah Nagari Silokek memahami bahwa pendidikan merupakan hal yang cukup krusial dalam pemgembangan Nagari Silokek untuk ke depannya.

\section{Pokdarwis Nagari Silokek}

Berdasarkan pada Surat Keputusan pembentukan Pokdarwis di Nagari Silokek Nomor: 188.45/528/KPTS-BPT-2019 Tentang Penetapan Kelompok Sadar Wisata terdapat 4 Pokdarwis 
di Nagari Silokek yakni Pokdarwis Muko-muko, Pokdarwis Pintu Ngalau, Pokdarwis Batang taye dan Pokdarwis Sangkiamo.

Tabel. 4 Nama Ketua Pokdarwis

\begin{tabular}{lll}
\hline No & \multicolumn{1}{c}{ Nama Pokdarwis } & \multicolumn{1}{c}{ Ketua Pokdarwis } \\
\hline 1 & Pokdarwis Sangkiamo & Andre Agustin \\
\hline 2 & Pokdarwis Muko-muko & Syamsuis \\
\hline 3 & Pokdarwis Batang Taye & Ramadial S.P \\
\hline 4 & Pokdarwis Pintu Ngalau & Maryaman (Dt. Kali Bandaro) \\
\hline & Sumber: SK Bupati Sijunjung No. $188.45 / 528 /$ KPTS-BPT-2019
\end{tabular}

Ketua Pokdarwis ini dipilih berdasarkan musyawarah bersama saat pembentukan Pokdarwis di Nagari Silokek di Balai-balai Nagari tahun 2019. Awal pembentukan Pokdarwis mulai dari usulan masyarakat yang ingin membentuk Pokdarwis berdasarkan pada potensi wisata yang ada di nagarinya dan keinginan untuk berpartisipasi mengembangkan wisata di nagarinya. Berawal dari usulan ini kemudian diusulkan kepada Pemerintah Daerah Kabupaten Sijunjung. Penetapan Pokdarwis Geopark Ranah Minang Silokek di Nagari Silokek Kabupaten Sijunjung ditetapkan secara resmi setelah dikeluarkannya SK Bupati Sijunjung No. 188.45/528/KPTS-BPT2019 tentang Kelompok Sadar Wisata di Kabupaten Sijunjung.

Tujuan dari pembentukan Kelompok Sadar Wisata (Pokdarwis) ini adalah sebagai berikut:

1. Meningkatkan posisi dan peran masyarakat sebagai subjek atau pelaku penting dalam pembangunan kepariwisataan, serta dapat bersinergi dan bermitra dengan pemangku kepentingan terkait dalam meningkatkan kualitas perkembangan kepariwisataan di daerah.

2. Membangun dan menumbuhkan sikap dan dukungan positif masyarakat sebagai tuan rumah melalui perwujudan nilai-nilai Sapta Pesona bagi tumbuh dan berkembangnya kepariwisataan di daerah dan manfaatnya bagi pembangunan daerah maupun kesejahteraan masyarakat.

3. Memperkenalkan, melestarikan dan memanfaatkan potensi daya tarik wisata yang ada di masing-masing daerah.

Tugas dari yang dijabarkan di atas merupakan tugas yang seterusnya dijalankan oleh Pokdarwis di Nagari Silokek. Ke empat Pokdarwis didasarkan pada tugas yang sama seperti yang telah dirincikan di atas. Tugas yang dirincikan di atas merupakan patokan dari berbagai tindakan yang dilakukan oleh Pokdarwis menjalankan program yang ada. Selanjutnya, Pokdarwis diharapkan dapat mewujudkan Sapta Pesona, konsep sadar wisata yang terkait dengan dukungan dan peran masyarakat sebagai tuan rumah dalam upaya untuk menciptakan lingkungan dan suasana kondusif yang mampu mendorong tumbuh dan berkembangnya industri pariwisata, melalui perwujudan unsur aman, tertib, bersih, sejuk, indah, ramah dan unsur kenangan.

\section{Pokdarwis Sebagai Agen Pengembangan Wisata Geopark Ranah Minang Silokek}

\section{Pokdarwis: Pemanfaatan Habitus}

Kelompok Sadar Wisata atau Pokdarwis menjadi ujung tombak dalam pembangunan pariwisata di Nagari Silokek dengan mengembangkan destinasi Geopark Ranah Minang. Visi yang dibangun yaitu pembangunan ekowisata yang tidak hanya berupaya untuk konservasi lingkungan alam, akan tetapi juga lingkungan sosial budaya yang dimiliki oleh masyarakat setempat. Point penting lainnya yaitu merancang supaya pembangunan pariwisata berkelanjutan dan dapat dinikmati juga oleh generasi selanjutnya.

Tujuan dari Pokdarwis dapat terlaksana dengan baik, salah satunya karena habitus yang dimiliki oleh masyarakat Nagari Silokek sejak lama, dan juga dimiliki oleh masyarakat Indonesia yaitu tradisi gotong royong. Gotong royong dapat dikatakan sebagai budaya lama dalam peradaban manusia, yakni berupa kegiatan kerja bakti secara bersama-sama (Irfan, 2016). Gotong royong menjadi kegiatan rutin yang dilakukan oleh Pokdarwis setiap sebulan sekali. Kegiatan ini dilakukan di lokasi yang menjadi tanggung jawab kelompok sadar wisata sesuai dengan 
kesepakatan yang sudah dibuat sebelumnya. Kegiatan gotong royong dilakukan dimulai dari penyusuran daerah yang menjadi target untuk dibersihkan dan kemudian dilakukan pembagian tugas sesuai dengan lokasi yang ada. Berdasarkan hasil wawancara dengan anggota Pokdarwis menyatakan sebagai berikut:

\begin{abstract}
"nan sangkek itu kami basamo-samo mambarosia pekarang di sapanjang nagoghi ko paliang rami katiko hari bersih-bersih tu katiko topek hari bersih-bersih dunianan tasobuik World Cleanup Daytdiak 19 September 2020. Jadi kami mambarosian wisata di nagoghi ko baok perlengkapan seadanyo se, ,mano nan dakek rumah warga, nah baok nyo mambarosian di sekitarannyo, jadi nan karajo awak sudah di tompek wisata nan rumah barasia lingkungan awak asri pulo."
\end{abstract}

terjemahan:

Ketika itu kami bersama-sama membersihkan perkarangan di sepanjang Nagari ini, yang paling ramai diadakan ketika bertepatan dengan hari bersih-bersih dunia dengan sebutan world Cleanup Day pada 19 September 2020. jadi kami membersihkan perkarangan wisata di nagari ini dengan perlengkapan seadanya saja, yang disekitaran rumah warga diajak membersihkan lingkungan sekitar rumahnya sendiri, jadi kerjaan kita selesai di lokasi wisata, rumah juga bersih dan lingkungan menjadi asri pula".

Pemaparan di atas menunjukkan bahwa masyarakat setempat secara langsung juga memberikan kontribusi terhadap kebersihan lingkungan sekitar dan mendukung pengembangan wisata Geopark di Nagari Silokek. Dalam hal ini Pokdarwis menjadi salah satu penggerak masyarakat melakukan kegiatan yang berdampak terhadap Geopark Ranah Minang Silokek. Kegiatan Gotong royong ini membuat intensitas pertemuan masing-masing anggota Pokdarwis semakin meningkat. Meningkatnya intensitas pertemuan ini juga akan berdampak pada pemahaman masing-masing anggota kelompok dengan kelompok lainnya samakin baik. Layaknya saudara saling menjaga dan mendukung satu dengan yang lainnya. Gotong royong yang merupakan budaya dan tradisi masyarakat menjadi salah satu modal penting untuk lebih memberdayakan masyarakat itu sendiri (Pranadji, 2009). Kegiatan gotong royong ini juga dapat menjadi contoh bagi generasi berikutnya agar tetap dilakukan secara turun-temurun.

Masyarakat Nagari Silokek sudah lama memiliki kebiasaan bergotong royong yang sudah ada dibentuk secara turun temurun di lingkungan masyarakat. Pokdarwis memiliki simbol di dalam masyarakat sebagai kelompok yang dianggap baik dan berkegiatan untuk kemajuan pariwisata di Nagari Silokek dengan, hal ini masyarakat turut berpartisipasi dan bekerjasama dengan Pokdarwis dalam berbagai kegiatan sebagai bentuk tindakannya salah satunya gotong royong bersama. Seperti yang disampaikan oleh Pierre Bourdieu dalam teori agen dan struktur bahwa praktek sosial berasal dari habitus dikalikan modal dan ditambah ranah yang ada didalam masyarakat bahwasanya masyarakat dibentuk dari lingkungan yang direnkonstruksi oleh agen.

Berdasarkan teori agen dan struktur Bourdiue menjelaskan bahwa kegiatan gotong royong yang dibalut dengan hari bersih-bersih dunia ini mengajak masyarakat ikut serta dalam kegiatan ini. Keikutsertaan masyarakat dan turut mengsukseskan kegiatan yang ada menunjukkan Pokdarwis berpengaruh dalam tindakan masyarakat. Pengaruh Pokdarwis ini menjadi Modal kapital yang dapat menakhlukkan masyarakat dan mengajak melakukan kegiatan untuk tujuan pengembangan wisata yang ada. Dengan kata lain Pokdarwis mempengaruhi struktur sebagai kelompok yang berpengaruh di dalam masyarakat. Pokdarwis menjadi agen dalam pengembangan wisata Geopark Ranah Minang Silokek.

\title{
Pokdarwis dan Pemanfaatan Modal (capital)
}

Modal (capital) secara umum diartikan sebagai material aset berupa benda-benda yang bernilai. Namun konsep modal dimaksudkan dalam tulisan ini yaitu melampaui gagasan aset material kapital yang dapat berupa modal sosial, modal budaya, atau modal simbolik (Bourdieu,

Culture \& Society: Journal of Anthropological Research Vol. 3, No. 1, Th. 2021 
1986: 241-258). Bourdieu meluaskan gagasan modal (capital) ke kategori-kategori seperti modal sosial, modal budaya, dan modal simbolik. Bagi Bourdieu, setiap individu menempati suatu posisi dalam ruang sosial multidimensional. Ruang itu tidak didefinisikan oleh keanggotaan kelas sosial, namun melalui jumlah setiap jenis modal yang ia miliki. Modal itu mencakup nilai jejaring sosial, yang bisa digunakan untuk memproduksi atau mereproduksi ketidaksetaraan.

Salah satu modal sosial yang dikembangkan oleh Pokdarwis dalam pengembangan pariwisata Geopark Ranah Minang di Nagari Silokek yaitu memperluas kerjasama dan membangun jejaring sosial. Kerjasama yang merupakan salah satu diantara bentuk interaksi sosial sebagai suatu bentuk proses sosial yang di dalamnya terdapat proses aktivitas untuk mencapai tujuan bersama dengan beragam bentuk kegiatan saling tolong-menolong dan memahami satu dengan yang lainnya (Abdulsyani, 1994). Mengadakan kerjasama dengan berbagai pihak merupakan salah satu upaya yang dilakukan dalam mengembangkan wisata Geopark Silokek di Nagari Silokek. Kerjasama dengan berbagai pihak sangat dibutuhkan dalam pengembangan pariwisata, mengadakan kerjasama dengan pihak-pihak tertentu maka, upaya pengembangan pariwisata menjadi lebih mudah, dan mengadakan kerjasama dengan pihak-pihak tertentu juga berpengaruh terhadap cepat atau lambatnya perkembangan pariwisata. Oleh karena itu perlu diadakannya kerjasama dengan pihak-pihak tertentu dalam upaya pengembangan wisata. Adapun kerjasama yang dilakukan pariwisata pemangku adat adalah sebagai berikut :

Pertama, kerjasama dengan pemangku Kerapatan Adat Nagari (KAN), Kerjasama yang dilakukan Pokdarwis dengan pemangku adat berupa pemberdayaan masyarakat adat sebagai Pokdarwis, sedangkan bagi Pokdarwis pemangku adat sebagai penasehat dan penyelesaian masalah saat terjadi konflik di dalam maupun di luar kelompok sebagai bagian dari masyarakat adat. Satu suku (clan) dalam satu kelompok menjadikan niniak mamak sebagai seorang yang dihormati di dalam Pokdarwis sebagai seorang pemangku adat. Hal ini sesuai dengan yang diungkapkan bapak Sirep 37 tahun sebagai malin pono suku Phatopang Bukik dari Pokdarwis Sangkiamo sebagai berikut:

\begin{abstract}
"kami di nagoghi ko kami masih kuek adat istiadatnyo, banyak keputusan nagoghi ko baambiak jo mampertimbangan pandapek niniak mamak. Jadi dek lokasi wisata ko ado di lokasi tanah punyo kaum suku, babagi lah sasuai jo lokasi suku sin soghang jadi ciek suku ciek loh Pokdarwis nyo. Kesepakatan iko lah daghi sado pihak mulai dari pemerintah, kami nan dari KANjo pemuda / i sarato jo sagalo masyarakat adat nak jan ado pacokakan isuak dek garagara tanah kaum di kelolah diak nan babeda suku. Lain dari pado itu kalau ado acar-acara adat kami torui malibatan Pokdarwis jadi dek acara adat ko ado juo wisatawan nan nio mancoiak mode Bakawua adat"
\end{abstract}

\begin{abstract}
Bahasa Indonesia:
“... kami di Nagari ini masih kuat adat istiadatnya, banyak keputusan nagari ini diambil dengan mempertimbangkan pendapat niniak mamak. Jadi karena lokasi wisata ini berada di lokasi tanah milik kaum suku, dibagikan sesuai dengan lokasi masingmasing suku maka satu Pokdarwis. Kesepakatan ini sudah disepakati semua pihak mulai dari pemerintah, kami yang dari KAN juga pemuda/i serta semua masyarakat adat supaya tidak ada pertengkaran dikemudian hari yang disebabkan tanah kaum dikelolah oleh yang berbeda suku. Selain dari hal itu kalau ada upacara adat Pokdarwis juga dilibatkan, untuk menambah wisatawan yang ingin melihat upacara adat seperti Bakawua adat."
\end{abstract}

Dari yang diungkapkan informan selain adanya kesepakatan untuk pembagian lokasi wisata juga menjadikan pemangku adat sebagai bagian penting dalam pengambilan keputusan. Tidak hanya perihal wisata saja namun juga turut melestarikan adat di Nagari Silokek. Seperti adanya upacara adat juga bisa dijadikan daya tarik wisata dan diperkenalkan oleh Pokdarwis kepada

Culture \& Society: Journal of Anthropological Research Vol. 3, No. 1, Th. 2021 
wisatawan. Hal ini dilakukan untuk meningkatkan jumlah kunjungan wisatawan dan meningkatkan kesejahteraan masyarakat Nagari Silokek.

Berdasarkan teori Agen dan Struktur dari Bourdieu terlihat bahwa Pokdarwis memanfaatkan modal kultur yang dimiliki untuk mengajak masyarakat berbuat sesuatu yang diharapkan Pokdarwis. Pokdarwis Mulai membentuk kebiasaan baru berdasarkan adat terdahulu untuk terus dilestarikan. Dengan modal kultural yang dimiliki Pokdarwis mendapatkan kepercayaan masyarakat dan ikutserta dalam kegiatan yang dilakukannya. Secara sederhanya hal ini juga mempengaruhi struktur masyarakat yang berubah dengan adanya kebiasaan baru dari kegiatan atau praktek yang dilakukan Pokdarwis dengan melibatkan Masyarakat.

Kedua, kerjasama dengan pihak BCA (Bank Central Indonesia) kerjasama dengan pihak BCA sebagai donatur utama dalam melaksanakan berbagai kegiatan Pokdarwis. Pokdarwis menjalankan kegiatan bersama dengan program BCA yakni Bakti BCA. Dalam hal ini pokdarwis akan bertindak sebagai penyelenggara kegiatan di lokasi wisata. Kerjasama dengan pihak BCA, dalam hal penyediaan sarana dan prasarana yang mendukung kemajuan Geopark Ranah Minang Silokek seperti diantaranya, penyediaan papan informasi mengenai Geopark Ranah Minang Silokek, tempat sampah, alat penyemprotan disinfektan dan sebagainya untuk mendukung kemajuan Geopark Ranah Minang Silokek Khususnya di Nagari Silokek.

Mengikuti Bourdieu bentuk kerjasama ini dapat terjadi dari adanya modal pengakuan Pokdarwis sebagai sebuah kelompok resmi yang diakui dari Surat Keputusan Bupati. Kemampuan komunikasi untuk menggaet sponsor dengan mengedepankan keunggulan wisata yang ada dan manfaat bagi sponsor dengan kerjasama bersama Pokdarwis, memberikan Pokdarwis modal kapital untuk melakukan berbagai kegiatan.

Pihak BCA berkegiatan dan bekerjasama dengan Pokdarwis dan mengikuti rangkaian kegiatan yang ada sehingga tercapai target kegiatan BCA, dan kegiatan Pokdarwis. Pokdarwis dapat bekerjasama dengan BCA, dengan modal yang ada untuk bekerjasama dan mencapai tujuan Pokdarwis yakni kelengkapan prasarana wisata seperti penyediaan papan Informasi di kawasan wisata Geopark Ranah Minang Silokek.

\section{Pokdarwis dan Ranah (field)}

Dalam mengembangkan destinasi wisata Geopark Ranah Minang, hal yang tidak dapat dipungkiri bahwa setiap lokasi wisata di daerah saat ini melakukan berbagai strategi untuk menggaet wisatawan, baik wisatawan lokal maupun wisatawan manca negara untuk datang berkunjung ke destinasi mereka, dan dapat menetap lama di masyarakat. Namun upaya itu tidak lah mudah, karena kondisi persaingan di antara berbagai destinasi akan terus terjadi, maka diperlukan berbagai strategi dalam rangka mewujudkan visi dan misi Pokdawis. Pariwisata sebagai ranah sosial dimana orang berjuang, bermanuver dalam mengejar sumberdaya yang diinginkan.

\section{Promosi Wisata}

Dalam rangka meningkatkan jumlah wisatawan dan memperkenalkan wisata Geopark kepada masyarakat luas tindakan yang dilakukan Pokdarwis dan pengelola Geopark Ranah Minang silokek yakni melalui promosi. Promosi menjadi salah satu cara memperkenalkan suatu hal kepada khalayak, dalam halnya pariwisata untuk meningkatkan jumlah wisatawan melalui informasi yang membujuk dan menonjolkan keunggulan pariwisata (Gita Atiko, Ratih Hasanah Sudrajat, 2016). Promosi dalah salah satu tindakan yang dipilih Pokdarwis untuk meningkatkan jumlah wisatawan. Adapun bentuk-bentuk promosi yang dilakukan yakni:

Pertama melalui media sosial, promosi melalui media sosial sangat ampuh dilakukan untuk meningkatkan jumlah kunjungan wisatawan di kawasan ini. Melalui instagram dengan nama Instagram@Geopark Ranah Minang Silokek, Facebook Geopark Ranah Minang Silokek. Calon wisatawan dapat melihat referensi tujuan di Geopark Silokek dan dokumentasi kunjungan wisata di kawasan ini. Dengan mengajukan paket wisata rafting, goa atau air terjun dan sebagainya.

Culture \& Society: Journal of Anthropological Research Vol. 3, No. 1, Th. 2021 
Gusrinda Gusrinda, Erda Fitriani Pokdarwis: Agen Pengembangan Wisata Geopark Ranah Minang Silokek

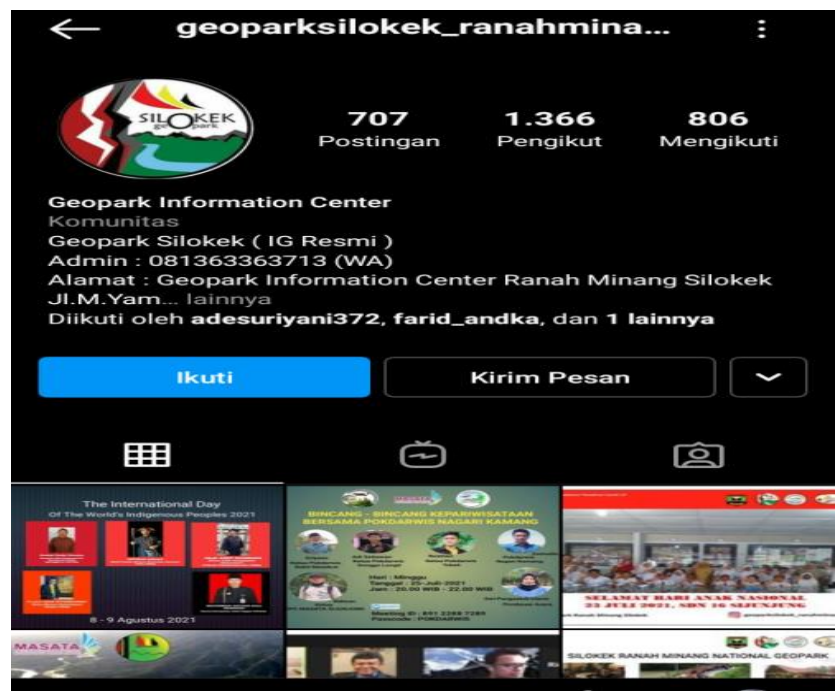

\section{Gambar 1. Akun Instagram Geopark Ranah Minang Silokek}

Akun resmi Geopark Ranah Minang Silokek ini dikelola oleh Badan Pengelola Geopark Ranah Minang Silokek. Badan Pengelola Geopark Ranah Minang Silokek ini merupakan badan yang menangungi langsung berbagai kegiatan yang dilakukan oleh Seluruh Pokdarwis yang Ada di Geopark Ranah Minang Silokek. Hal ini dilakukan untuk tetap menjaga kesatuan Pokdarwis dalam satu Geopark yang berada di dua Kecamatan.

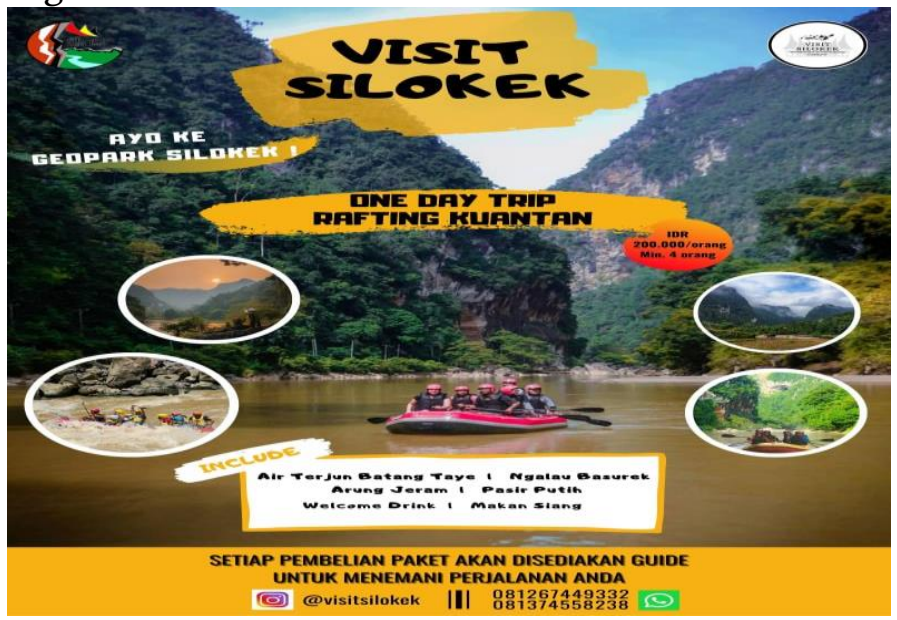

Gambar 2. Pamflet Paket Wisata

Gambar di atas merupakan salah satu pamflet yang dibuat oleh koordinator antar Pokdarwis di Nagari Silokek. Pamflet ini merupakan salah satu bentuk usaha promosi yang dilakukan yang disebarkan melalui media sosial baik berupa Instagram, Whatsapp, maupun facebook resmi dari Geopark Ranah Minang Silokek. Pamflet juga disebarkan melalui akun pribadi yang dimiliki oleh anggota Pokdarwis, dan berbagai pihak yang turut bekerjasama untuk mengembangkan wisata Geopark di Nagari Silokek. Pemanfaatan teknologi informasi ini menjadi salah satu upaya untuk mengeliminasi keterbatasan pengetahuan yang dimiliki masyarakat (Hamzah Ritchi, Reza M. Zulkarnaen, 2018). Terlebih lagi era digital yang memanfaatkan teknologi dalam berbagai kegiatan.

Kedua promosi secara langsung melalui sosialisasi, Berdasarkan observasi yang dilakukan peneliti pada April 2021 di kawasan wisata Geopark Nagari Silokek melihat adanya kunjungan dari sekolah setingkat TK, SD dan SMP/Sederajat yang berkunjung ke rest area dan pasir putih di wisata Geopark Nagari Silokek. Saat dilakukan wawancara dengan Pokdarwis yang sedang piket 
di kawasan Rest Area bahwa kunjungan ini bagian dari Program School Go to Geopark yang merupakan lanjutan program Silokek Goes to School yang sudah pernah dilaksanakan sebelumnya. Ini merupakan hubungan timbal balik dan juga dalam mengedukasi peserta didik untuk lebih mencintai lingkungan dan alam sekitar.

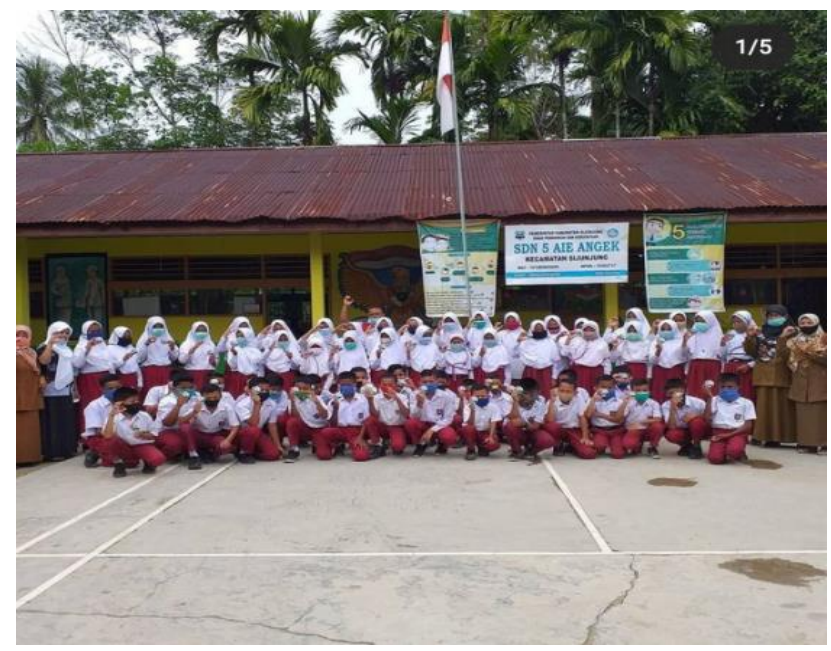

\section{Gambar. 3 Geopark Goes to School Pada 2 Maret 2021 di SDN 5 Aie Angek}

Gambar di atas memperlihatkan bahwa sudah dilakukannya kunjungan ke sekolah oleh Pokdarwis dan Badan Pengelola Geopark Ranah Minang Silokek untuk memperkenalkan Geopark kepada siswa. Kunjungan ini akan bertukar atau berlanjut dengan balasan kunjungan School Go to Geopark agar siswa berbaur langsung dengan alam.
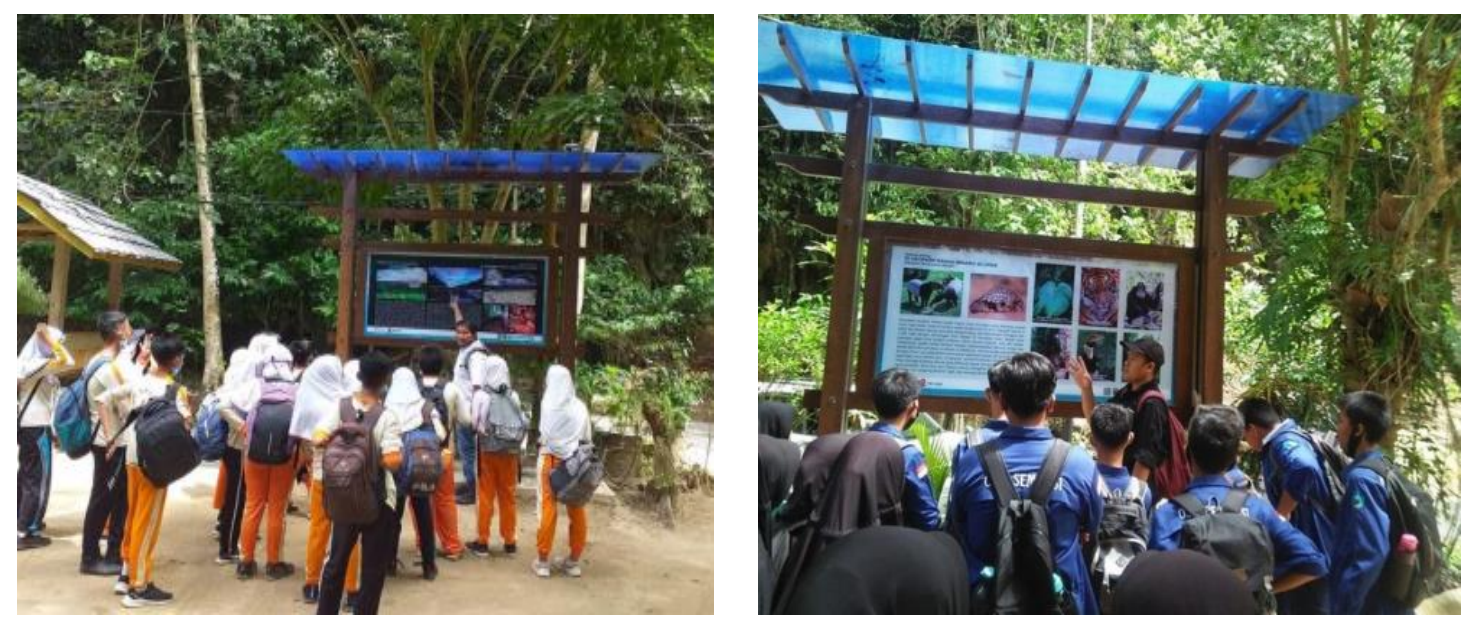

Gambar.4 (Shool goes to Geopark Pada 5 dan 6 April 2021)

Kunjungan Sekolah ke kawasan Geopark Ranah Minah Silokek Nagari Silokek ini merupakan program bersama Badan Pegelola dengan Pokdarwis. Program ini selain memperkenalkan Geopark kepada siswa juga mengedukasi kecintaan siswa terhadap alam untuk menjaga dan merawat alam. Program ini adalah program dengan efek timbal balik yang sebelumnya juga sudah dilakukan kunjungan Geopark Goes to School.

Berdasarkan pada gambaran di atas menjelaskan bahwa Pokdarwis juga memanfaatkan media sosial dan kemampuan mengajak orang lain secara langsung melalui sosialisasi untuk melakukan hal yang diharapkan oleh Pokdarwis yakni mengunjungi kawasan wisata Geopark Ranah Minang Silokek. media sosial dan kemampuan untuk berkomunikasi merupakan modal kultural dan sosial yang dimiliki oleh Pokdarwis. Dengan adanya modal ini membantu Pokdarwis melakukan tindakan untuk tercapainya tujuan Pokdarwis. 
Analisis teori agen dan struktur dari Bourdieu dengan perkembangan media sosial untuk berinteraksi bagi masyarat promosi melalui media sosial merupakan pilihan yang sesuai untuk saat ini. Kebiasaan mengakses media sosial bagi kalangan milenial ini dimanfaatkan oleh Pokdarwis memaparkan potensi wisata yang ada di Geopark Ranah Minang Silokek, dalam hal ini Pokdarwis menjadi agen promotor memperkenalkan wisata yang ada.

Kegiatan promosi ini tidak hanya bagi Pokdarwis namun juga turut dilakukan oleh pemuda nagari dalam promosi wisata, rasa persaudaraan dan kedaerahan yang kuat sehingga pemuda merasa perlu ikut serta melakukan promosi yang dilakukan Pokdarwis. Modal kultur Pokdarwis terlihat jelas bagi pemuda nagari. Pemuda nagari mengupayakan dengan sumberdaya yang ada untuk membantu kegiatan Pokdarwis ini.

\section{Pemberdayaan Masyarakat sebagai ranah (field)}

Salah satu strategi yang dilakukan oleh Pokdarwis dalam meningkatkan pemahaman masyarakat mengenai pariwisata ekologi, dan supaya pengembangan pariwisata dapat menjadi upaya sadar dan tidak sadar yang dimiliki oleh masyarakat yaitu dengan melakukan edukasi.

\section{Sosialisasi}

Berdasarkan pada observasi yang dilakukan peneliti pada April 2021 di kawasan wisata Geopark Nagari Silokek melihat adanya kunjungan dari sekolah setingkat TK, SD dan SMP/Sederajat yang berkunjung ke rest area dan pasir putih di wisata Geopark Nagari Silokek. Saat dilakukan wawancara dengan Pokdarwis yang sedang piket di kawasan Rest Area bahwa kunjungan ini bagian dari Program School go to Geopark yang merupakan lanjutan program Silokek Goes to School yang sudah pernah dilaksanakan sebelumnya. Ini merupakan hubungan timbal balik dan juga dalam mengedukasi peserta didik untuk lebih mencintai lingkungan dan alam sekitar.

Kunjungan Sekolah ke kawasan Geopark Ranah Minang Silokek Nagari Silokek ini merupakan program bersama Badan Pegelola Geopark dengan Pokdarwis. Program ini selain memperkenalkan Geopark kepada siswa juga mengedukasi kecintaan siswa terhadap alam untuk menjaga dan merawat alam. Program ini adalah program dengan efek timbal balik yang sebelumnya juga sudah dilakukan kunjungan Geopark Goes to School.

\section{Pelatihan}

Pelatihan yang dilakukan oleh Pokdarwis merupakan kerjasama dengan badan pengelola Geopark Ranah Minang Silokek. Dalam bentuk pengembangan wisata Geopark Ranah Minang Silokek ini perlu diadakannya pelatihan untuk Pokdarwis dalam mengelola wisatanya. Kegiatan pelatihan dapat dijadikan cara alternatif meningkatkan sumber daya manusia (Turere, 2013). Pelatihan ini memberikan bekal untuk Pokdarwis baik soft skill maupun hard skill dalam mengelola wisata yang ada. Pokdarwis di Nagari Silokek mengikuti pelatihan sesuai dengan kebutuhan destinasi wisatanya. Berikut Pelatihan untuk Pokdarwis di Nagari Silokek:

\section{Arung Jeram (Rafting)}

Pelatihan arung jeram dilakukan 2 kali dalam satu bulan di Sungai Batang Kuatan. Perlengkapan arung jeram yang ada berupa perahu karet, dayung, pelampung, helm, tali (flip line), P3K dan Pompa udara sudah disediakan oleh Disnas Pariwisata Pemuda dan Olahraga. Pelatihan ini di pandu oleh anggota pokdarwis yang sudah mengikuti kejuaraan arung jeram tingkat nasional yang juga dengan tim dari Nagari Silokek.

\section{Pemandu Wisata (Tour Guide)}

Pelatihan menjadi seorang pemandu wisata dilakukan untuk semua anggota Pokdarwis di Nagari Silokek. Pelatihan ini diadakan untuk memberikan wawasan yang luas kepada Pokdarwis dan meningkatkan kemampuan publik speaking. Pokdarwis dalam hal ini bertindak sebagai pemandu wisatawan yang berkunjung ke wisata Geopark di Nagari silokek. 


\title{
Pembuatan Sovenir
}

Pelatihan pembuatan sovenir ini dilakukan untuk pokdarwis dalam memanfaatkan barang bekas unuk diolah menjadi souvenir yang dapat memiliki nilai jual. Souvenir yang dibuat juga identik dengan Geopark Ranah Minang Silokek baik berupa tulisan maupun lukisan bertemakan Geopark Ranah Minang Silokek. Berdasarkan wawancara yang dilakukan dengan ketua Pokdarwis Pasir putih bapak Mayarman yang sering dipanggil dengan Datuak Kali mengungkapkan bahwa:

\begin{abstract}
" pelatihan mambuek sovenir ko lah lamo di kojoan, tapi kini sajak covid-19 ko lah dak ado kerumunan lai dak loh ado pelatihan mambuek sovenir di lai. Kok dek ambo lai ancak juo ado maagia pemasukan ka urang awak nan nan bakojo. Biaso a sakali sabulan ado jia a pelatihan ko mah, lah sudah dilatih bulan isuak nyo laporkan perkembangan hasil pelatihan tu dan produk yang dihasilkan ka ketua Pokdarwis, beko bisa samo-samo di kumpuan di tompek penjualan sovenir nan di dokek gua basurek tu, kini lah dak ado nampak lai. Pelatihan ko awalnyo kami dak loh nio ikuik de, tapi mancoliakPokdarwis uwang awak-awak isi e yo, cubocubo luh nan dak bisa kini lah bisakok kak mambuek lapiak pandan, gantuangan kunci, dan banyak lai."
\end{abstract}

Bahasa Indonesia:

Pelatihan pembuatan souvenir ini pernah dilakukan sebelumnya, namun semenjak adanya pandemi Covid-19 kegiatan ini sudah tidak dilakukan lagi. Pelatihan tidak lagi dilakukan untuk menghindari kerumunan di tempat pelatihan. Berbagai produk yang dihasilkan dari pembuatan souvenir akan dikumpulkan di satu tempat dan dijual kepada para wisatawan yang uang hasil penjualannya akan dimasukkan ke dalam Kas Pokdawis. Pelatihan ini awalnya kami juga gak mau ikut, namun karena orang-orang sekampung isinya, tetap dicoba-coba awalnya gak bisa sekarang sudah bisa membuat tikar pandan, gantungan kunci, dan banyak lagi yang lain.

Pernyataan di atas menjelaskan bahwa pelatihan pembuatan souvenir terhenti semenjak adanya pandemi Covid-19. Tidak adanya pelatihan dan produksi souvenir juga tidak diteruskan sehingga tidak adanya pemasukan untuk kas Pokdarwis. meski demikian berdasarkan pada observasi yang penulis lakukan pada 5 April 2021 jumlah wisatawan terlihat masih ada dan tidak mengalami pengurangan hanya saja kegiatan Pokdarwis lebih difokuskan pada pemeriksaan protokol kesehatan bagi wisatawan seperti penggunaan masker, mencuci tangan dan tidak berkerumun di area wisata.

Kegiatan pelatihan ini merupakan lanjutan dari adanya kerjasama yang dilakukan Pokdarwis dengan pihak Dinas Pariwisata Pemud dan Olahraga. Pelatihan ini dapat memberikan modal kultural berupa skill atau kemampuan kepada Pokdarwis. Kemampuan ini berasal hari hal yang dilakukan secara berulang-ulang dan dapat mempengaruhi kebiasaan dan pemikiran seseorang atau kelompok untuk melakukan suatu hal. Kemampuan Pokdarwis seperti berbicara di depan wisatawan menjadi pemandu wisata tidak didapatkan begitu saja. Kemampuan ini didapatkan dari membiasakan untuk berbicara yang dipahami oleh orang lain memiliki pesan yang disampaikan dan mental yang berani dalam menyampaikan informasi di depan wisatawan. Dengan kemampuan ini juga dapat mempengaruhi pemikiran orang lain (wisatawan) terhadap wisata yang ada di Geopark Ranah Minang Silokek agar wisatawan kembali mengunjungi wisata ini.

\section{Pokdarwis Melakukan Eksplorasi Destinasi Wisata Baru}

Dalam beberapa kesempatan Pokdarwis menelusuri kawasan Geopark, menemukan beberapa lokasi yang dapat dijadikan destinasi wisata yang baru. Kegiatan Pokdarwis dalam mengeksplorasi destinasi wisata baru ini tidak tidak dijadwalkan untuk melakukannya. Kesiap siagaan Pokdarwis saat penemuan destinasi wisata baru terlihat dari kecepatan respon. Hal ini secara tidak langsung sudah menjadi bagian dari pengembangan wisata Geopark Ranah Minang

Culture \& Society: Journal of Anthropological Research Vol. 3, No. 1, Th. 2021 
Silokek yang dilakukan Pokdarwis. Keterbukaan dan kepercayaan masyarakat terhadap Pokdarwis terlihat dari pengaduan yang ada, dapat disimpulkan bahwa Pokdarwis dapat merekonstruksi kebiasaan masyarakat untuk mengonfirmasi hal-hal baru yang ditemukan.

Kegiatan untuk eksplorasi wisata baru hanya akan dapat dilakukan dengan modal kepercayaan dari berbagai pihak agar Pokdarwis dapat mengelolah sesuai dengan yang semestinya. Kebiasaan masyarakat yang sudah menganggap Pokdarwis sebagai pengelola wisata Geopark Ranah Minang Silokek membiasakan masyarakat untuk bertindak dan membantu Pokdarwis. Adanya Pokdarwis mempengaruhi tindakan masyarakat tanpa disadari oleh masyarakat. Keberadaan Pokdarwis membawa berbagai perubahan dalam tindakan masyarakat terhadap hal-hal baru sehubungan dengan wisata yang mereka temukan. Disini terlihat bahwa Pokdarwis sebagai agen pengembangan wisata Geopark Ranah Minang Silokek, kemampuan Pokdarwis mempengaruhi dan membentuk praktek sosial berupa tindakan masyarakat sejalan dengan yang dikemukakan Bourdieu bahwa bahwa sebagai agen akan mempengaruhi struktur dalam pembentukan kebiasaan baru, dengan memanfaatkan modal yang ada untuk mempengaruhi individu lainnya melakukan sesuai keinginan agen.

Berdasarkan pada semua pemaparan bahwa adanya kerjasama, promosi, pemberdayaan masyarakat, dan eksplorasi wisata baru yang dilakukan Pokdarwis ini sudah memberikan pengaruh bagi lingkungan masyarakatnya. Pengaruh terhadap lingkungan masyarakat ini menyentuh berbagai kalangan termasuk siswa sekolah dan masyarakat umum. berbagai kegiatan yang dilakukan Pokdarwis membentuk kebiasaan baru di dalam masyarakat Nagari Silokek. layaknya pernyataan Pierre Bourdieu tentang habitus yakni suatu hal yang biasa atau cenderung dilakukan baik oleh individu maupun keompok yang dibentuk oleh lingkungannya. Dari hal ini Pokdarwis juga memiliki legitimasi kekuasaan untuk mempengaruhi masyarakat dan kelompokkelompok yang ada di lingkungannya yang disebut Bourdieu sebagai field atau arena yang didukung oleh adanya modal ekonomi dari pokdarwis sendiri dan donatur, modal kemampuan Pokdarwis dari adanya pelatihan, modal relasi sosial atau jaringan, dan diadakannya kerjasama dengan berbagai pihak, serta modal simbolik berupak SK yang dikeluarkan Bupati Sijunjung menetapkan Pokdarwis di Nagri Silokek. Dari semua pernyataan ini menghasilkan suatu tindakan atau praktek sosial di dalam masyarakat dengan Pokdarwis sebagai agennya.

\section{Kesimpulan}

Habitus dari agen ini dapat mempengaruhi masyarakat untuk turut serta melakukan berbagai tindakan pembaharuan untuk perkembangan wisata Nagari Silokek. Kemampuan Pokdarwis mengajak masyarakat sebagai bentuk penaklukan dari modal yang dimiliki oleh Pokdarwis. Pokdarwis mampu memanfaatkan sumber daya yang ada untuk mencapai tujuan pengembangan wisata Geopark Ranah Minang Silokek.

Berdasarkan hasil penelitian ini mengungkapkan bahwa Pokdarwis di Nagari Silokek merupakan agen penggerak yang mengembangkan wisata Geopark Ranah Minang Silokek. Sebagai agen penggerak, pokdarwis Ranah Minang Silokek menjadi acuan bagi masyarakat dalam bertingkah laku untuk mengembangkan wisata Geopark Ranah Minang Silokek. Pokdarwis sebagai agen memanfaatkan potensi wisata nagari yang ada untuk meningkatkan kesejahteraan masyarakat di Nagari Silokek. Untuk penelitian ini peneliti belum sampai pada tahap mengembangkan model wisata berkelanjutan sesuai dengan konsep ekowisata yang diusung di geopark. Pada penelitian selanjutnya disarankan untuk lebih mengembangkan penelitian tentang model wisata berkelanjutan seperti konsep ekowisata yang sesuai dengan geopark Ranah Minang Silokek. Selanjutnya juga dapat diperluas untuk subjek penelitian pada Pokdarwis di dua Kabupaten sebanyak 28 Pokdarwis yang ada di Geopark Ranah Minang Silokek. 


\section{Daftar Pustaka}

Abdulsyani, R. (1994). Sosiologi, Sitematika, Teori dan Terapan. Jakarta: Bumi Aksara.

Amelia, M. B. (2016). Strategi Pengembangan Kawasan Ekowisata Musiduga Melalui Pendekatan Arsitektur Strategi. Institut Pertanian Bogor.

Coban, S. (2012). The Effects of the Image of Destination on Tourist Satisfaction and Loyality. Jurnal of Social Science, 222-232.

Creswell, john w. (2016). Research Design Pendekatan Metode Kualitatif, Kuantitatif dan Campuran (1 ed.). Yogyakarta: Pustaka Pelajar.

Gita Atiko, Ratih Hasanah Sudrajat, K. N. (2016). Analisis Strategi Promosi Pariwisata Melalui Media Sosial Oleh Kementrian Pariwisata RI. Jurnal Sosioteknologi, 15(1), 1-10.

Hardani, H. (2020). Metode Penelitian Kualitatif \& Kuantitatif. Kalangan Yogyakarta: CV Pustaka Ilmu Group Yogyakarta.

Harker, R. (2009). (Habitus x Modal)+ Ranah= Praktik: Pengantar Paling Komprehensif kepada Pemikiran Pierre Bourdieu, terj. Pipit Maizier, Yogyakarta: Jalasutra.

Hamzah Ritchi, Reza M. Zulkarnaen, Z. D. dan Y. P. (2018). Pemanfaatan Teknologi Informasi dalam Upaya Peningkatan Aksesbilitas UKM (Desa Wisata) Kepada Pasar di Lokasi Wisata Pangandaran Dan Sekitarnya. Jurnal Pengabdian Kepada Masyarakat, 2(1), 36-40.

Hidayat, M. (2011). Strategi Perencanaan dan Pengembangan Objek Wisata (Studi Kasus Pantai Pangandaran Kabupaten Ciamis Jawa Barat. Jurnal Tourism and Hospitality Essentials (THE), $1(1), 33-44$.

Irfan, M. (2016). Metemorfosis Gotong Royong dalam Pandangan Konstruksi Sosial. Prosiding KS: Riset dan PKM, 4(1), 140.

Kusuma, D. W. (2019). Geopark Silokek Sijunjung Menuju UNESCO Global Geopark Sijunjung Silokek Geopark Towards UNESCO Global. Geopark: Jurnal Pembangunan Nagari, 4(1), 1732.

Nurlestari, A. F. (2016). Pengaruh Daya Tarik Wisata Terhadap Niat Kunjungan Ulang Wisatawan Dengan Kepuasan Wisatawan Sebagai Variabel Intervening Pada Taman Safari Indonesia Cisarua Bogor. Jurnal Pariwisata, 16(1).

Nurwafi, L. (2015). Institusional Enterpreneurship Pemuda Dalam Mengembangkan Pokdarwis Desa Wisata Nglanggeran. Jurnal Studi Pemuda, 4(1).

Pranadji, T. (2009). Penguatan Kelembagaan Gotong Royong Dalam Perspektif Sosio Budaya Bangsa. Jurnal Forum Penelitian Agro Ekonomi, Volume. 27(1), 61-72.

Putrawan, P. E., \& Ardana, D. M. J. (2019). Peran Kelompok Sadar Wisata (Pokdarwis) Dalam Pengembangan Pariwisata Di Desa Munduk Kecamatan Banjar Kabupaten Buleleng. Locus, 11(2).

Rauf, A., \& Eriyanti, F. (2019). Pemberdayaan Masyarakat Nagari Sijunjung Melalui Pemanfaatan Rumah Gadang Sebagai Tempat Penginapan Wisatawan Geopark Silokek. Jurnal Perspektif, 2(3), 170-178.

Schott, J. (2012). Teori Sosial. Yogyakarta: Pustaka Pelajar.

Turere, V. N. (2013). Pengaruh Pendidikan Dan Pelatihan Terhadap Peningkatan Kinerja Karyawan Pada Balai Pelatihan Teknis Pertanian Kalasey. Jurnal EMBA, Vol. 1, Hal. 10-19.

Umam, C., Pangesti, F. S. P., \& Yuslistyari, E. I. (2020). Pemberdayaan Pokdarwis Tazgk Dalam Pengembangan Desa Wisata Di Kaduengang. Sawala: Jurnal pengabdian Masyarakat Pembangunan Sosial, Desa dan Masyarakat, 1(1), 17-22. 